\title{
CHARACTERIZATION OF INTERANNUAL AND SEASONAL PATTERNS AND EXTREMES IN 41 YEARS OF PRECIPITATION DATA FROM BELTERRA, PARÁ, BRAZIL
}

Troy Patrick Beldini, Rodrigo da Silva, Fabíola Carolina Pereira Valente, David Fitzjarrald

\section{RESUMO}

Este trabalho identificou padrões interanuais e sazonais, e meses com valores extremos de precipitação total num conjunto de dados de precipitação mensal de 41 anos da Belterra, no oeste do Estado do Pará, Brasil. Apesar de intensas mudanças no uso da terra nos últimos anos e a variabilidade natural da precipitação na região, nenhuma tendência foi descrita para precipitação total anual, sazonal ou eventos extremos.

\begin{abstract}
The objective of this work is to identify interannual and seasonal patterns in precipitation, and quantify extreme precipitation totals in a 41-year monthly precipitation data set from Belterra in western Pará State, Brazil. In spite of recent intense land use change and natural climate variability in the region, no trends were found for annual, seasonal, or extreme precipitation totals.
\end{abstract}

\section{INTRODUCTION}

During recent years the Amazon basin has been the focus of researchers interested in describing natural and anthropogenic influences on climate variation in the region (Costa et al., 2007; Fitzjarrald, et al., 2008; Rocha et al., 2009). Studies of precipitation variation are made even more important due to the fact that during the last few decades the Amazon region has been undergoing intense land use changes, principally for installation of mechanized agriculture (Cerri, et al. 2005; Costa et al., 2007; Hayhoe et al., 2011; Neill et al., 2013). Between 2003 and 2009 the Belterra region in Pará experienced a 7-fold and 28fold increase in hectares planted with soy and corn, respectively (CONAB, 2012|). Land-use changes, coupled with large natural inter-annual variability in rainfall regimes in the region (Fisch et al. 1996; Nobre et al., 2007), could modify local hydrologic regimes (Nobre et al., 
2007; Silva Dias 2008) and impact agricultural and development activities. Recent results of modeling (Costa et al., 2007) and field studies (Davidson et al., 2012) in eastern Amazonia show a decrease in evapotranspiration and precipitation, and extreme events in precipitation (drought and flooding) are predicted to increase in the region (Marengo et al., 2009).

The objective of this work is to identify interannual and seasonal patterns in precipitation, and quantify extreme precipitation totals in a 41-year monthly precipitation data set from Belterra in western Pará State, near the Tapajos River, an important location near a strong regional precipitation gradient (Fitzjarrald et al., 2008).

\section{METHODS AND MATERIALS}

Data were collected at the National Meteorological Institute (INMET) Belterra station during 1972 through 2012 on a daily basis using a standard wedge gauge. Data were analyzed using regression of precipitation totals over the 41-year period. Monthly precipitation totals were divided into annual, 6-month and 3-month intervals to analyze for seasonal trends. Months were also analyzed on an individual basis, i.e., all the months of January (41), etc., in order to detect trends. Additionally, the Standardized Precipitation Index (SPI) was used to describe extremely dry or wet climate situations. The SPI is obtained by fitting a gamma or a Pearson Type III distribution to monthly precipitation values (McKee et al., 1993). The SPI is the number of standard deviations (SD) that the observed value for a month would deviate from the long-term mean for that month, for a normally distributed random variable. The SPI results can be divided into the following classes:

\begin{tabular}{|c|c|c|}
\hline $\begin{array}{c}\text { SPI value } \\
\text { (number of SD from the long-term mean) }\end{array}$ & SPI Class & Interpretation \\
\hline $\mathrm{x} \leq-2$ & 1 & Extremely dry \\
\hline$-2<\mathrm{x} \leq-1.5$ & 2 & Severely dry \\
\hline$-1.5<\mathrm{x} \leq-1$ & 3 & Moderately dry \\
\hline$-1<\mathrm{x} \leq 1$ & 4 & Near normal \\
\hline $1<\mathrm{x} \leq 1.5$ & 5 & Moderately wet \\
\hline $1.5<\mathrm{x} \leq 2$ & 6 & Severely wet \\
\hline $\mathrm{x} \geq 2$ & 7 & Extremely wet \\
\hline
\end{tabular}




\section{RESULTS}

Missing data for this dataset is limited to the month of September, 1976, and 8 other days. Precipitation totals for all years are shown in Figure 1. Data for the year 1985 were omitted from this analysis as the values were abnormally high for the annual total and several months. The authors suspect there may have been a malfunction with equipment and/or collection procedures, and since there was no way of verifying this, the data were omitted.

Figure 1. Total annual precipitation, Belterra, Pará, 1972 - 2012 (line is average: 1905 mm).

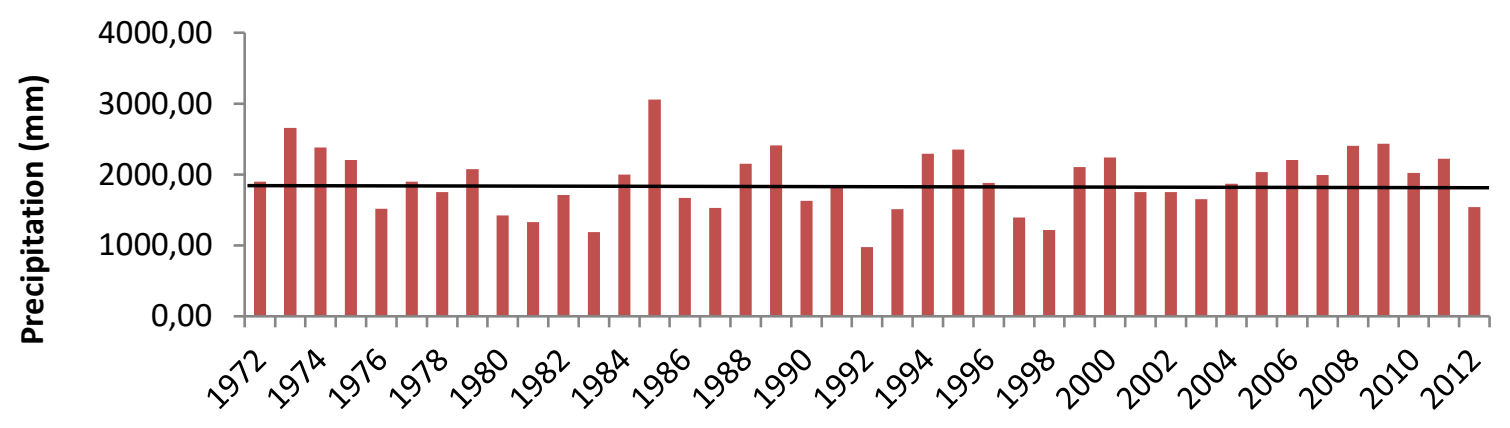

Table 1 shows the regression results for the annual and seasonal precipitation totals from the last 41 years, and these data show no apparent trend.

Table 1. Correlation and regression coefficients for annual and seasonal precipitation totals, Belterra, Pará, 1972 - 2012

\begin{tabular}{|c|c|c|}
\hline Precipitation totals & $\mathbf{r}$ & $\mathbf{r}^{\mathbf{2}}$ \\
\hline Annual & 0,095 & 0,009 \\
\hline 6-month rainy season (January - June) & 0,19 & 0,036 \\
\hline 6-month dry season (July - December) & $-0,14$ & 0,021 \\
\hline 3-month rainy season (January - March) & 0,19 & 0,035 \\
\hline 3-month rainy season (April - June) & 0,12 & 0,015 \\
\hline 3-month dry season (July - September) & $-0,095$ & 0,009 \\
\hline 3-month dry season (October - December) & $-0,14$ & 0,019 \\
\hline
\end{tabular}


The SPI analysis for months with extreme values for precipitation $( \pm 1.5 \mathrm{SD}$ from the longterm mean for that month) are shown in Table 2. The data were divided into four decades and each decade was divided into a rainy season (January to June) and a dry season (July to December).

Table 2. Number of months with extreme precipitation total for each decade and season

\begin{tabular}{|c|c|c|c|c|c|c|c|c|}
\hline \multirow{2}{*}{$\begin{array}{c}\text { SPI Class } \\
\text { (number of SD from the long- } \\
\text { term mean for that month) }\end{array}$} & \multicolumn{2}{|c|}{$1972-1981$} & \multicolumn{2}{|c|}{$1982-1991$} & \multicolumn{2}{|c|}{$1992-2001$} & \multicolumn{2}{|c|}{$2002-2012$} \\
\hline & Rain & Dry & Rain & Dry & Rain & Dry & Rain & Dry \\
\hline Extremely dry & 2 & 1 & 2 & 1 & 4 & 3 & 2 & 0 \\
\hline $\begin{array}{ll}2 & (-2<\mathrm{x} \leq-1.5) \\
\text { Severely dry }\end{array}$ & 3 & 2 & 1 & 0 & 2 & 2 & 2 & 2 \\
\hline $6(1.5<\mathrm{x} \leq 2) \quad$ Severely wet & 1 & 7 & 2 & 2 & 3 & 2 & 2 & 4 \\
\hline Extremely wet & 0 & 1 & 0 & 0 & 0 & 0 & 1 & 1 \\
\hline
\end{tabular}

\section{DISCUSSION}

Correlation and regression for annual and seasonal precipitation totals (Table 1) show no apparent trends for increase or decrease in precipitation on a yearly, 6-month seasonal, or 3month seasonal basis during the 41-year interval. Likewise, the analysis of extreme monthly precipitation totals (Table 2) does not reveal any trend in extreme precipitation totals between the four decades of this study. Further analysis of these data could include a comparison with data from stations located more inland to compensate for the possible bias induced by the Tapajós river breeze (Fitzjarrald, et al. 2008), and also might support the proposition made by Marengo (2009) that multi-decadal variations in precipitation in this region (and the Amazon in general) are governed by cycles rather than trends. Additionally, correlations of extreme events of precipitation or drought with the occurrence of El Niño and La Niña events could be conducted to provide local-scale support for the hypothesis of the existence of cycles of precipitation, as opposed to temporal trends, in the Belterra region.

\section{CONCLUSIONS}


These data demonstrate that, in spite of the intense land-use changes and large natural variability in climate in the region, there is no pattern to change in precipitation totals during the last 41 years at the Belterra INMET station.

\section{ACKNOWLEDGMENTS}

The authors thank the Instituto Nacional de Meteorologia (INMET) for the dataset.

\section{LITERATURE CITED}

Cerri, C.C et al. 2005. Recent history of the agriculture of the Brazilian Amazon Basin. Outlook on Agriculture, Vol. 34, No. 4, p. 215-223.

CONAB, 2012. (www2.conab.gov.br/download/sureg/PA/). Acesso em 22 ago 2013.

Davidson, E.A. et al. 2012. The Amazon Basin in Transition. Nature

Fisch, G., et al. 1996. Clima da Amazônia, MCT/INPE/CPTEC- Instituto Nacional de Pesquisas Espaciais, Cachoeira. Paulista SP, 24-41.

Fitzjarrald, D.R. et al., 2008. Spatial and temporal rainfall variability near the AmazonTapajos confluence. Journal of Geophysical Research, Vol. 113, G00B11.

Hayhoe, S.J., et al. 2011. Conversion to soy on the Amazonian agricultural frontier increases streamflow without affecting stormflow dynamics. Global Change Biology, vol. 17 (5), p. $1821-1833$

Marengo, J. A., et al. 2009. Future change of temperature and precipitation extremes in South America as derived from the PRECIS regional climate modeling system. Int. J. Climatol., 15, 2241-2255.

Marengo, J. A. 2009. Long-term trends and cycles in the hydrometeorology of the Amazon basin since the late 1920s. Hydrol. Process. doi: 10.1002/hyp.7396

McKee, T. B., et al. 1993: The relationship of drought frequency and duration of time scales. Eighth Conference on Applied Climatology, American Meteorological Society, Jan17-23, 1993, Anaheim CA, pp.179-186. 
Neill, C., et al. 2013. Watershed responses to Amazon soya bean cropland expansion and intensification.Philos Trans R Soc Lond B Biol Sci. 368(1619):20120425.

Nobre, C.A. et al. 2007. Mudanças climáticas e a Amazônia. SBPC, Ciência e Cultura, p.1-6.

Rocha, H.R. et al. 2009. Patterns of water and heat flux across a biome gradient from tropical forest to savanna in Brazil. Journal of Geophysical Research, Vol. 114, G00B12.

Silva Dias, M.A.F. 2008. Forest and Rainfall Interactions in the Amazon Basin. Terrae, $3(1): 46-53$. 